\title{
Towards the scale-up of bioelectrogenic technology: Stacking microbial fuel cells to produce larger amounts of electricity
}

Y. Asensio, E. Mansilla, C.M. Fernandez-Marchante, J. Lobato, P. Cañizares, M.A. Rodrigo*

Department of Chemical Engineering. Faculty of Chemical Sciences \& Technologies. Universidad de Castilla La Mancha. Campus Universitario s/n 13071 Ciudad Real. Spain.

\begin{abstract}
Experimental work carried out in this work has investigated the scale-up of microbial fuel cell (MFC) technology by studying the stacking of single microbial fuel cells, paying attention to the electric and hydraulic connections between each unit. To do this, the performance of three stacks (which were set up with different configurations) was studied for more than three months. The first stack (two hydraulically non-connected cells) was operated for 80 days without any electric connection between them, in order to determine the reproducibility of the performance of a single $\mathrm{MFC}$, and then it was electrically connected in parallel for 20 days to determine if the electricity produced by each single cell was added when they were joined in the stack. The other two stacks (with five and ten cells, hydraulically connected) were connected electrically in series during the first 80 days and in parallel during the last 20 days. The results confirmed that connection in parallel allows higher current intensities and power to be obtained, and that the total electrode surface area attained with the stack is directly related to the production of electricity and to the removal of COD, although not in a linear way.
\end{abstract}




\section{Keywords}

Microbial fuel cells; stacking; scale-up; electric connection

\section{Introduction.}

Microbial fuel cells (MFC) are bioelectrochemical devices that may directly transform the chemical energy contained in the chemical bonds of the organic matter into electricity, using microorganisms' metabolism. In the search for alternatives to the negative environmental consequences of the use of conventional fossil fuels, they are becoming a promising topic of research [1-6]. Thus, in recent decades, a great deal of attention has been paid to MFCs as a technology to obtain clean energy from waste such as urban wastewater or industrial effluents, taking into account the capacity of the MFCs to recover this energy by degrading pollutants contained in the wastewater[7]. However, this is not the only application of MFCs that has been researched, and currently, their evaluation as devices to power small equipment with different purposes is also a hot topic, worthy of research [8]-[9]. In fact, it is the most realistic application of this technology because the low demands of these equiptments could be powered by this type of power sources

Conventional MFCs consist of an anodic compartment where microorganisms oxidize the organic fuel, and a cathodic compartment where oxygen is reduced to water. The compartments are usually separated by a proton exchange membrane (PEM) [10]. The electrical efficiency of MFCs depends on multiple factors such as electrode material [11-14], 
cell configuration [15-17], microorganisms' cultures [18-21], and fuel characteristics such as organic load[22, 23], conductivity and $\mathrm{pH}[24]$.

Despite the huge research efforts made in the last decades, the total amount of energy produced by a single MFC is still very low for real applications and far from an applicability target [25-27]. Thus, the scale-up of MFCs is necessary and stacking seems to be the best choice, because the increase of the electrode surface area does not lead to the expected results, perhaps because of the large ohmic resistances associated with these special types of power sources [28-31]

Regarding stacking: theoretically, the connection of single MFCs in series could be a solution to improve the voltage, while the parallel connection should be a very efficient method to increase current capacity. However, electricity is not the only parameter that should be connected between cells, because fuel and comburent feeding need also to be defined in this scale-up procedure[32-35]. Different authors have previously faced scale-up of the technology and have observed how the energy produced increases as compared to single MFCs $[25,36]$. However, because of the large number and high interelation of the processes involved, this scale-up is not a simple procedure and many problems have been found when it has been tried, this being currently an interesting topic for further research[37-44]. For example, Dekker built a stacked MFC of $20 \mathrm{~L}$ of volume, using synthetic wastewater obtaining low energy generation of $11 \mathrm{~W} \mathrm{~L}^{-1}$, due to the possible effect of voltage reversal in some cells of the system[45]. To avoid this problem, a progressive scaling of the technology had to be carried out.

In this work, three different stacks were operated for more than three months and tested in order to determine how the connection of single MFCs can enhance electrical output for real applications. The effects of the hydraulic and electric connections were evaluated in terms 
of degradation of the COD contained in the wastewater and in terms of the electricity production. Hydraulic connection may have a great influence because the efficiency of each single MFC is expected to be higher as the concentration of substrate increases in the nearness of the anodes. The sequential pass of same fuel throught different cells can lead to the partial exhaustion of its organic load and hence affect to this efficiency. Electric connection is also important because of the low current produced, which may be very severely affected by the parasitic loses associated to the electric connection of single cells.

\section{Materials and Methods.}

\subsection{Experimental Set-up.}

The set-ups used in this research consisted of three different stacks of MFCs: Stack 1(two stacked-MFCs), Stack 2 (five stacked-MFCs), and Stack 3 (ten stacked-MFCs). A scheme is shown in Figure 1.

All the single-MFCs that formed all the different stacked-MFCs consisted of two chambers $\left(4 \mathrm{~cm}^{3}\right.$ volume in each one), separated by a proton exchange membrane, PEM (Sterion $\left.{ }^{\circledR}\right)$, which has a high ionic conductivity $\left(0.9-0.02 \mathrm{meq} \mathrm{g}^{-1}\right)$ and low electronic conductivity $(8 \mathrm{x}$ $\left.10^{-2} \mathrm{~S} \mathrm{~cm}^{-1}\right)$. An MFC is formed by two phenolic resin plates and two silicon plates in order to improve the mechanical properties and avoid liquid leakage. Carbon felts (KFA10, SGL Carbon Group ${ }^{\circledR}$ ) were used as electrodes in both chambers (each one being $7 \mathrm{~cm}^{2}$ ). 


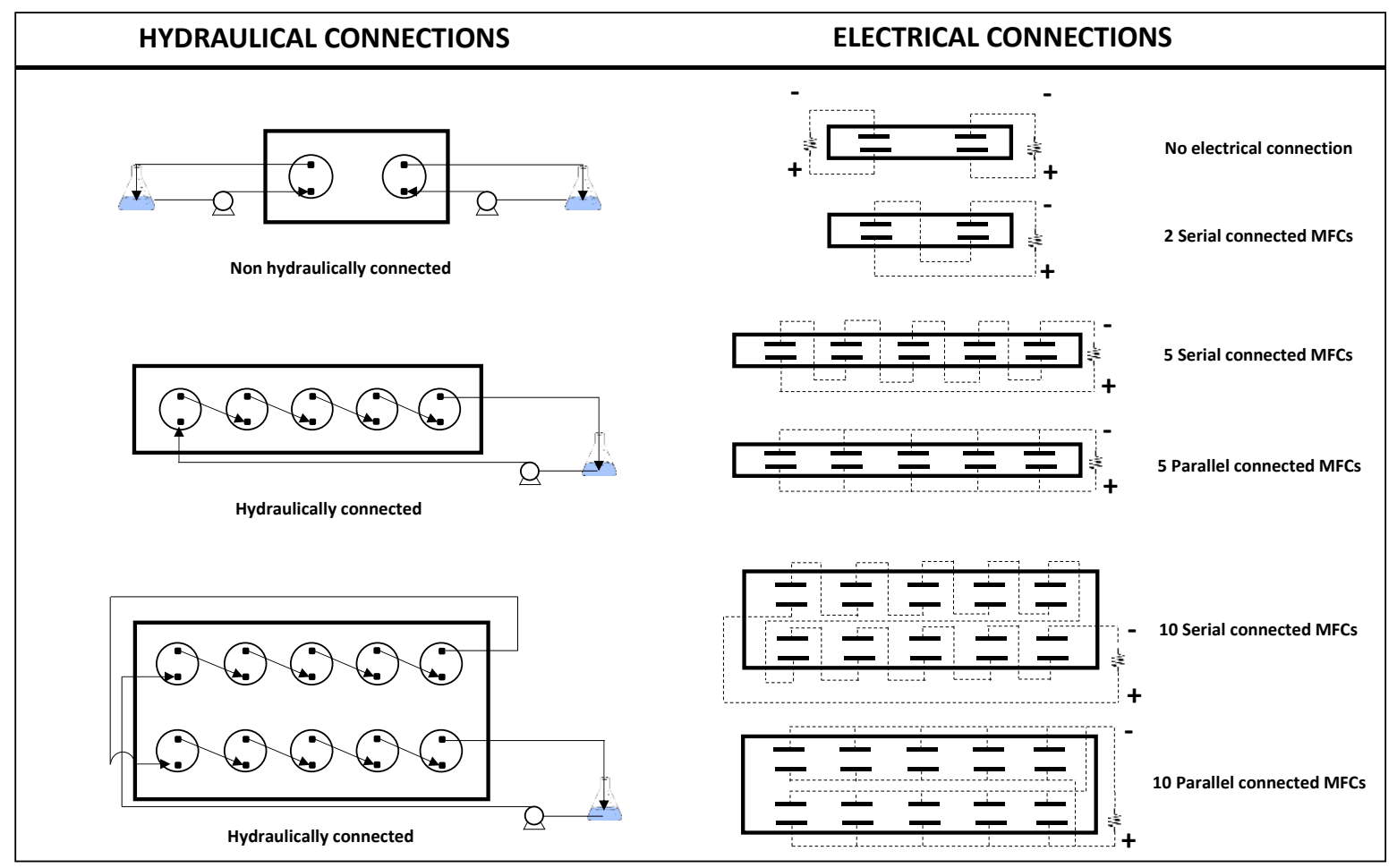

Figure 1. Scheme of the three stacks tested in this work.

The space between the electrodes was minimized in order to reduce the ohmic drops as much as possible. The electrodes were connected serially and in parallel during the experiments and an external resistance $\left(\mathrm{R}_{\mathrm{ext}}\right)$ of $120 \Omega$ was used to complete the electric circuit; this $\mathrm{R}_{\text {ext }}$ was chosen to operate in a proper range of intensities and voltages, preventing activation losses $[46,47]$. The stacked-MFCs studied in this work were operated simultaneously in semi-continuous mode and at room temperature $\left(24 \pm 2^{\circ} \mathrm{C}\right)$. The cathode compartments were connected to a water reservoir of $100 \mathrm{~cm}^{3}$ and a peristaltic pump was used to circulate an $\mathrm{HCl}$ solution ( $\mathrm{pH}$ 3) from the reservoir to a cathode compartment in order to avoid a low concentration of protons that could decrease the electrical efficiency of the biological reactors. A fishery compressor was placed in the cathode reservoir to provide oxygen to the solution, the flow rate being $1.6 \mathrm{~L} \mathrm{~min}^{-1}$. 


\subsection{Inoculum and Substrates.}

Activated sludge from a wastewater treatment plant (Ciudad Real, Spain) was used as inoculum for the anodic compartment. The activated sludge was preconcentrated by a sedimentation process and placed in the anodic compartment without aeration in order to favor the formation of an anaerobic mixed culture of microorganisms for three days. During these three days, no synthetic wastewater was added to the microorganisms' culture. In all cases, inorganic and organic compounds of the synthetic wastewater were the same for the different stacked-MFCs (see Table 1).

Table 1: Synthetic wastewater composition

\begin{tabular}{cc}
\hline Compound & Concentration $(\mathbf{g} / \mathbf{L})$ \\
\hline $\mathrm{NaCH}_{3} \mathrm{COO}$ & 12.01 \\
$\mathrm{NaHCO}_{3}$ & 2.77 \\
$\left(\mathrm{NH}_{4}\right)_{2} \mathrm{SO}_{4}$ & 1.85 \\
$\mathrm{KH}_{2} \mathrm{PO}_{4}$ & 1.11 \\
$\mathrm{MgCl}_{2}$ & 0.92 \\
$\mathrm{CaCl}_{2}$ & 1.25 \\
$\left(\mathrm{NH}_{4}\right) \mathrm{Fe}\left(\mathrm{SO}_{4}\right)_{2}$ & 0.07 \\
\hline
\end{tabular}

The stacked-MFCs were fed once a day. Nevertheless, the operation process can be considered as semi-continuous within long periods of time. Hydraulic retention time (HRT) was the same for all devices ( $3.16 \mathrm{~d}$ ). To avoid the change of parameters that could affect the electricity generation of the stacked-MFCs, all devices were operated at the same time, maintaining all input parameters in the same value, even the nutrient solution. The concentration of these inorganic and organic compounds was high enough for them to not become limiting reagents.

\subsection{Experimental Procedure.}


A digital multimeter (Keithley 2000 multimeter) was connected to the external electric circuit to continuously monitor the cell voltage of each stacked-MFC at the value of the external resistance $(120 \Omega)$ [46, 47]. Chemical oxygen demand (COD) in the output effluent was evaluated using a Velp ECO-16 digester and a Pharo100 Merck spectrophotometer analyzer. $\mathrm{pH}$, conductivity, and dissolved oxygen were measured with a GLP22 Crison $\mathrm{pH}$ meter, a Crison Cm 35 conductivity meter, and an Oxi538 WTW oxy meter, respectively. Polarization curves were measured in all the stacked-MFCs. Three important parameters were evaluated: open circuit voltage (OCV) - or the maximum voltage value without the external loads - the maximum intensity and the maximum power density of all the stacked-MFCs. The polarization curves can be divided into three important zones: a decrease of the current due to the activation loses, a linear decrease due to the ohmic loss (at this point, the internal resistance of each stacked-MFC could be calculated), and the third zone at high intensities and low voltages that give information about the mass-transfer limitations (due to the concentration losses).

\section{Results and Discussion.}

Figure 2 shows the changes measured, over a 100-day period, in the COD of the anodic compartments of the three stacked-MFCs tested in this work, named as Stack 1 (two cells), Stack 2 (five cells) and Stack 3(10 cells). All of them were fed simultaneously with the same synthetic wastewater, so the input of organic and inorganic compounds was the same in all cases, including the influent COD shown in both plots. Part A compares this influent COD with the COD measured at the outlet of the two cells that form Stack 1. In this case, the two 
cells were fed separately with the same wastewater and two different effluents were formed, not related to each other from the hydraulic point of view. A comparison of the results obtained in both will help to check the reproducibility of these systems. Meanwhile, Part B compares the influent COD with the COD of the outlet of Stacks 2 and 3, for which the effluent of each of the cells that form the stacks becomes the influent of the next cell. Hence, there is only one common oulet in each stack, corresponding to the outlet of the last MFC stacked in the device. Stack 2 is smaller, because it is made up of five single MFCs, while Stack 3 connected 10 single cells in series from the hydraulic point of view. No other differences can be found between both devices. It is important to bear in mind that MFCs are set up with a reservoir tank, from which the anolyte is continuously recirculated to the cell, in order to favor suitable mixing conditions and easy operation. This means that in the case of Stack 1, there are two different (and not related) reservoir tanks, while in the case of Stacks 2 and 3, there is only one reservoir tank for each stack. Nevertheless, the feeding procedure consists of replacing - every day - a volume of the mixed liquor contained in this tank with fresh wastewater. The volume of the reservoir tank is always the same $\left(100 \mathrm{~cm}^{3}\right)$ and it is very high when compared to the surface area of the anodes $\left(7 \mathrm{~cm}^{2}\right.$ each) or the volume of the anodic compartment $\left(4 \mathrm{~cm}^{3}\right.$ each). This means that a very important contribution of suspended culture can be expected, and any discussion should not be limited solely to the performance of the microorganisms fixed on the anode surface or those contained in the vicinity (anode compartment), although they are going to be more strongly related to the electrochemical processes, because electrochemical processes become less important as the distance to the electrode increases, which in turn is explained because the ohmic resistances increase in an important way with this input. Another important consideration in understanding the results compared in this work is that there were two 
separate periods of operation, marked by a discontinuous line in the graphs. They underwent exactly the same conditions from the substrate feeding point of view and they only differed in the type of electric connection applied between the cells that form the stack.
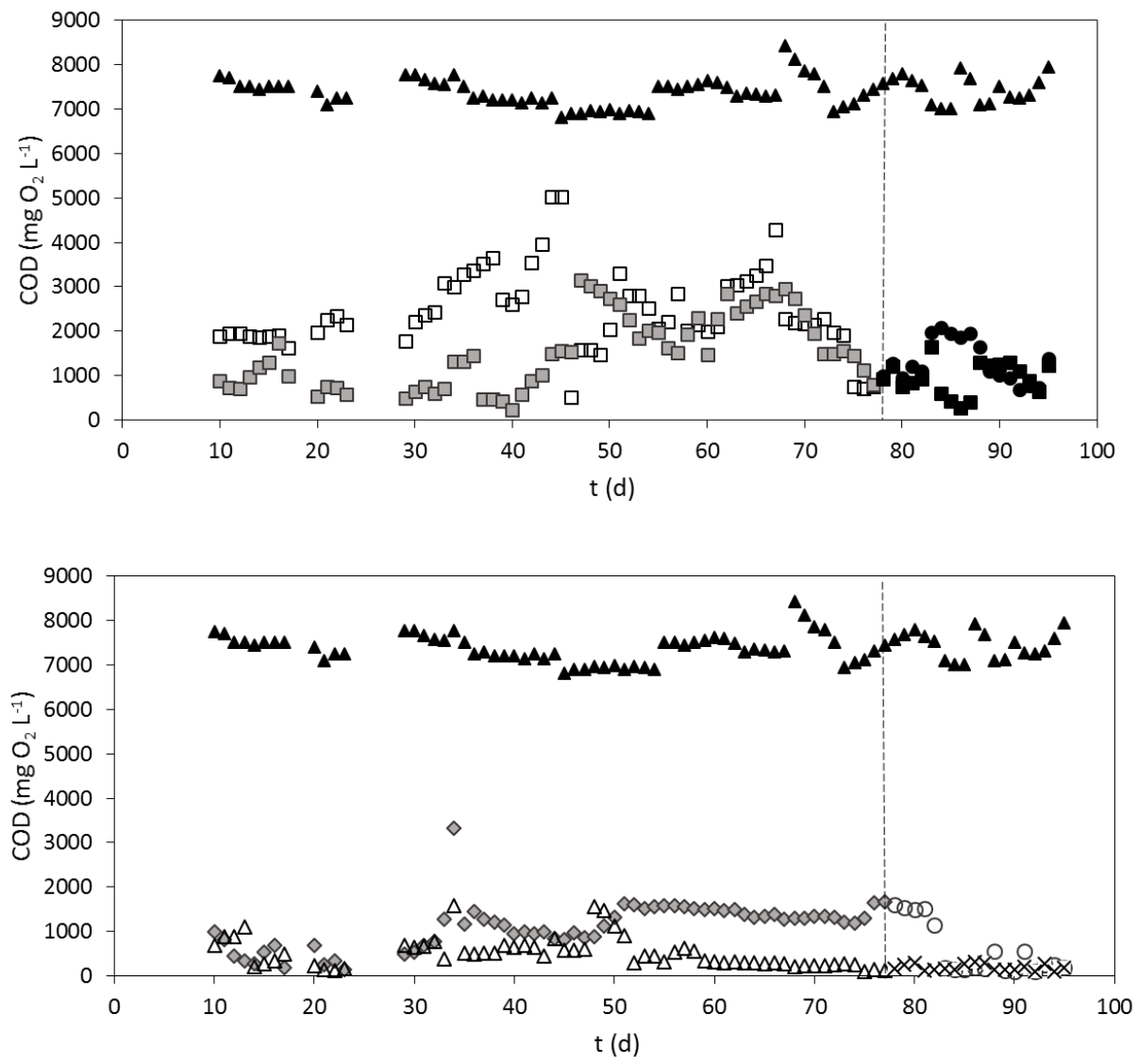

Figure 2. Changes in the COD during the operation of Stack 1 (Part A) and Stacks 2 and 3 (Part B) during the two periods of the test. Separated MFCs of Stack 1 ( $\square$ MFC1 and MFC2) prior to their electrical connection; Stack 1 connected in parallel $(\bullet \mathrm{MFC} 1$ and -MFC2); Stack 2 connected in series $(\diamond)$; Stack 2 connected in parallel (O); Stack 3 connected in series $(\triangle)$; Stack 3 connected in parallel $(\mathrm{x})$.

Taking all these into account, as can be observed, COD is partially consumed in all tests by the microorganisms contained on the anodes and in the anodic compartments. As can be 
deduced from the results of Stack 1, a single cell is not enough to deplete the COD load, although a very important consumption is obtained. In comparing the two effluents obtained for Stack 1, it can be stated that COD consumption has a great reproducibility because the two systems lead to very similar COD removals, in particular when the system is left to reach a stationary response (for the period between days 50 and 70). Likewise, in comparing the two effluents produced by Stack 1 with the single effluents of Stacks 2 and 3, it can be observed that the COD consumption increases with the anodic area of the stack $\left(7 \mathrm{~cm}^{2}\right.$ in the case of the two cells of Stack 1, $35 \mathrm{~cm}^{2}$ in the case of Stack 2 and $70 \mathrm{~cm}^{2}$ in the case of Stack 3), despite the significant volume of the reservoir tanks, which is the same in the four cases $\left(100 \mathrm{~cm}^{3}\right)$. This means that surface processes have a significant influence on the performance of the stacks, despite the very important volume of the reservoir tank, and contribute in an important way to the overall COD removal. It is important to bear in mind that in all the tests, the HRT, room temperature, and nutrient solution were kept within the same values for the three stacks in order to improve the reproducibility of the bioelectrochemical process. Hence, the changes in COD removal and electricity generation are only due to the different number of stacked-MFCs in each device and to the electric connection between cells.

Another important observation that can be made from the three stacks is that the long-term COD concentration tends toward stationary values in all cases, as is expected for semicontinuous reactive systems, such as the stacks studied in this work. In fact, within long periods the bioreactor has to be considered as a continuous reactor, while for shorter periods it behaves like a discontinuous reactor, as can be appreciated in the cycles shown in Figure 3, corresponding to three selected days of operation and for which the effect of the feeding cycle can be clearly observed. Taking into account this behaviour as a continuous process using long-period approaches, the COD consumption rate can be obtained using a mass 
balance, taking into consideration this flowdynamic approach for the stacked-MFCs, using Equation 1, where $\mathrm{q}$ stands for the daily flowrate, $\mathrm{V}$ is the total electrolyte volume (anodic compartment and reservoir) and $\mathrm{r}_{\mathrm{COD}}$ is the COD consumption rate. Subindex 0 refers to inlet and 1 to outlet.

$$
q C O D_{o}-q C O D_{1}+r_{C O D} V=V \frac{d C O D_{1}}{d t}
$$
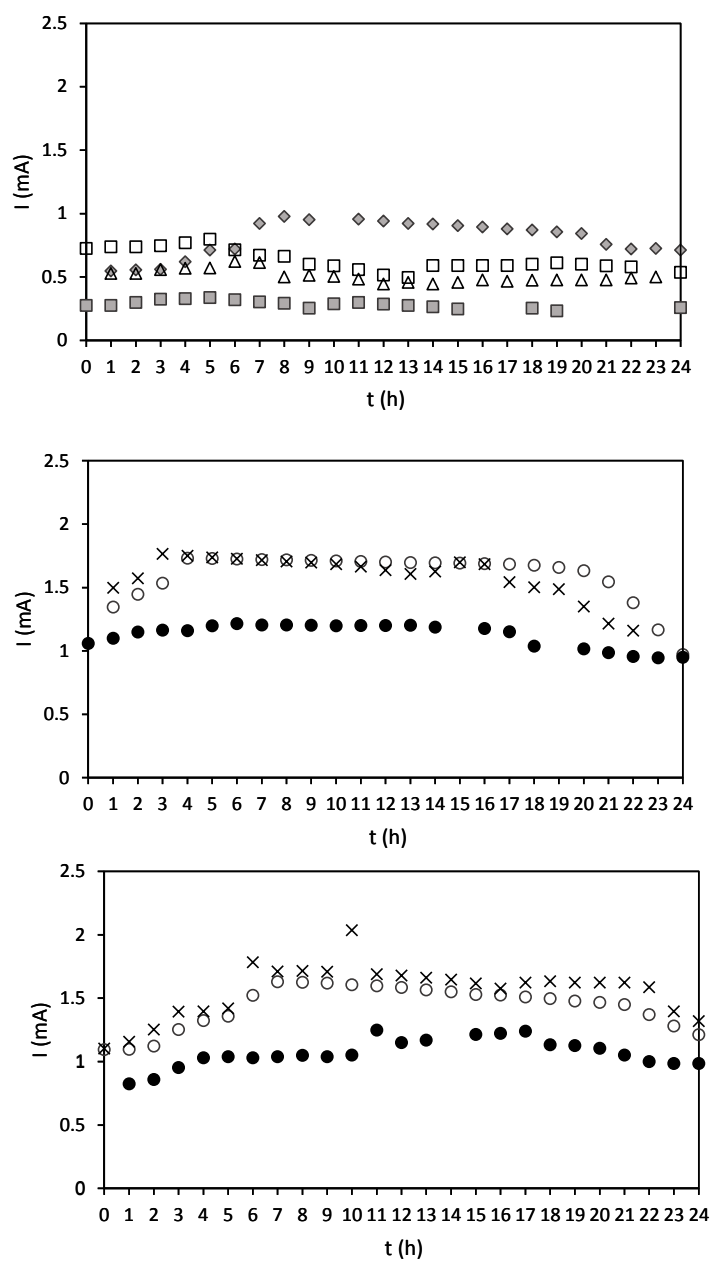

Figure 3. Daily profiles in the current produced over the 49th (upper), 83th (middle) and $89^{\text {th }}$ (bottom) days of operation. Separated MFCs of Stack 1 ( $\square$ MFC1 and $\square$ MFC2) prior to their electrical connection; Stack 1 connected in parallel (•); Stack 2 connected in series 
$(\diamond)$; Stack 2 connected in parallel $(O)$; Stack 3 connected in series $(\triangle)$; Stack 3 connected in parallel (x).

Figure 4 compares the values of stationary COD consumption in the three stacks during the two operation periods by representing it versus the anode area. In addition to the improved COD consumption rate with an increase in the anode surface area, it can be seen how the change in the electric connection of Stack 1 leads to an increase in the COD consumption of each cell, suggesting a positive effect. Likewise, the change in Stacks 2 and 3 from series to parallel was also reflected in a more important COD consumption. It is important to remark that in all cases the removal of COD was very effective, and hence it may be limiting the rate of the process.

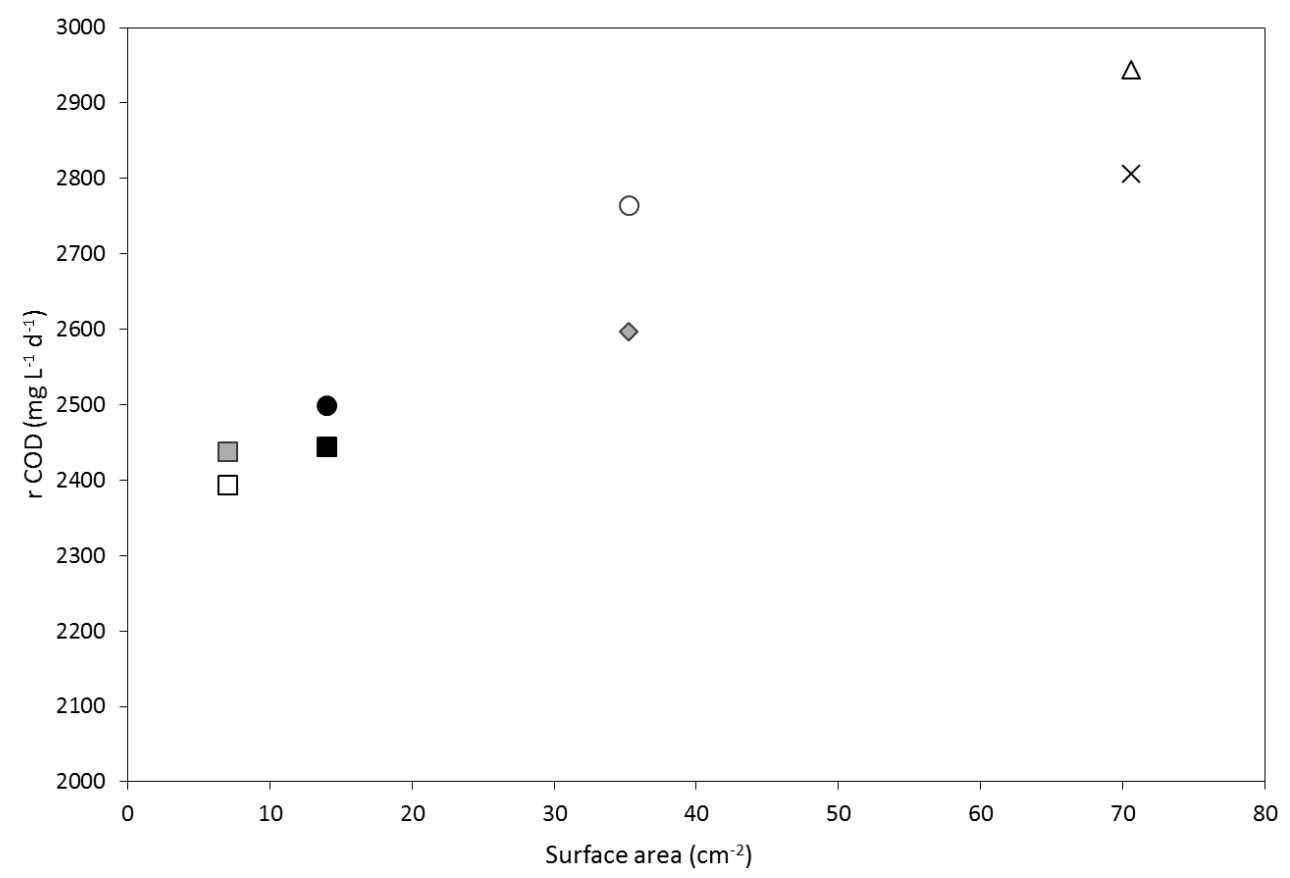

Figure 4. Influence of the type of electric connection and anode surface area on the stationary COD consumption rate. Separated MFCs of Stack 1 ( $\square$ MFC1 and $\square$ MFC2) prior to their electrical connection; Stack 1 connected in parallel ( MFC1 and $\mathbf{M F C 2})$; Stack 2 
connected in series $(\diamond)$; Stack 2 connected in parallel $(O)$; Stack 3 connected in series $(\triangle)$; Stack 3 connected in parallel (x).

COD is the main operating parameter of a microbial fuel cell if we consider it as an environmental technology but not when we study MFC as an energy power source. In this case, the current intensity produced becomes the more important parameter. The changes in the current intensity produced by the three stacks over the 100-day operation period are shown in Fig.5. Clearly, it can be distinguished as a first stage in which no electricity was produced, followed by a second stage in which the current produced rises exponentially and which lasts with the stabilization in the production of current. These three periods can be easily associated with the well-known latent, exponential and stationary growth of any microbial culture and they are typically observed during the acclimation of most MFCs. Here, we are observing that this is also the case when MFCs are connected in stacks. An important factor that should be pointed out is that the three phases were not observed in the COD removal, and this difference can be explained by taking into account that bioelectricityproducing microorganisms are generated from the microorganisms seeded, progressively replacing the non-bioelectrogenic microorganisms in the removal of COD.

Another very important observation that is obtained from the comparison of the two cells that form Stack 1 (Part A) is that - opposite to what happened with COD removal - great differences are observed between the electricity produced by both cells. During the first period, the cells were operated as single MFCs and no electric or hydraulic connection existed. As both MFCs are within the same conditions, the significant differences confirm the difficulties faced in finding reproducible results when operating with MFCs, most likely because of the very large number of inputs involved in the complexity of the microbial 
processes. This is a very important weakness of MFC technology, because here no differences in the inputs were produced.

A last important point about the performance of Stack 1 can be obtained by the comparison of Periods 1 and 2. When cells were electrically connected in parallel (keeping their own hydraulic circuit without any changes), an increase in the current intensity was produced, as expected. This increase corresponds to the addition of the effect of the two cells, although the variability is very important, taking into account the day-profiles generated with the way of operation of the cells.
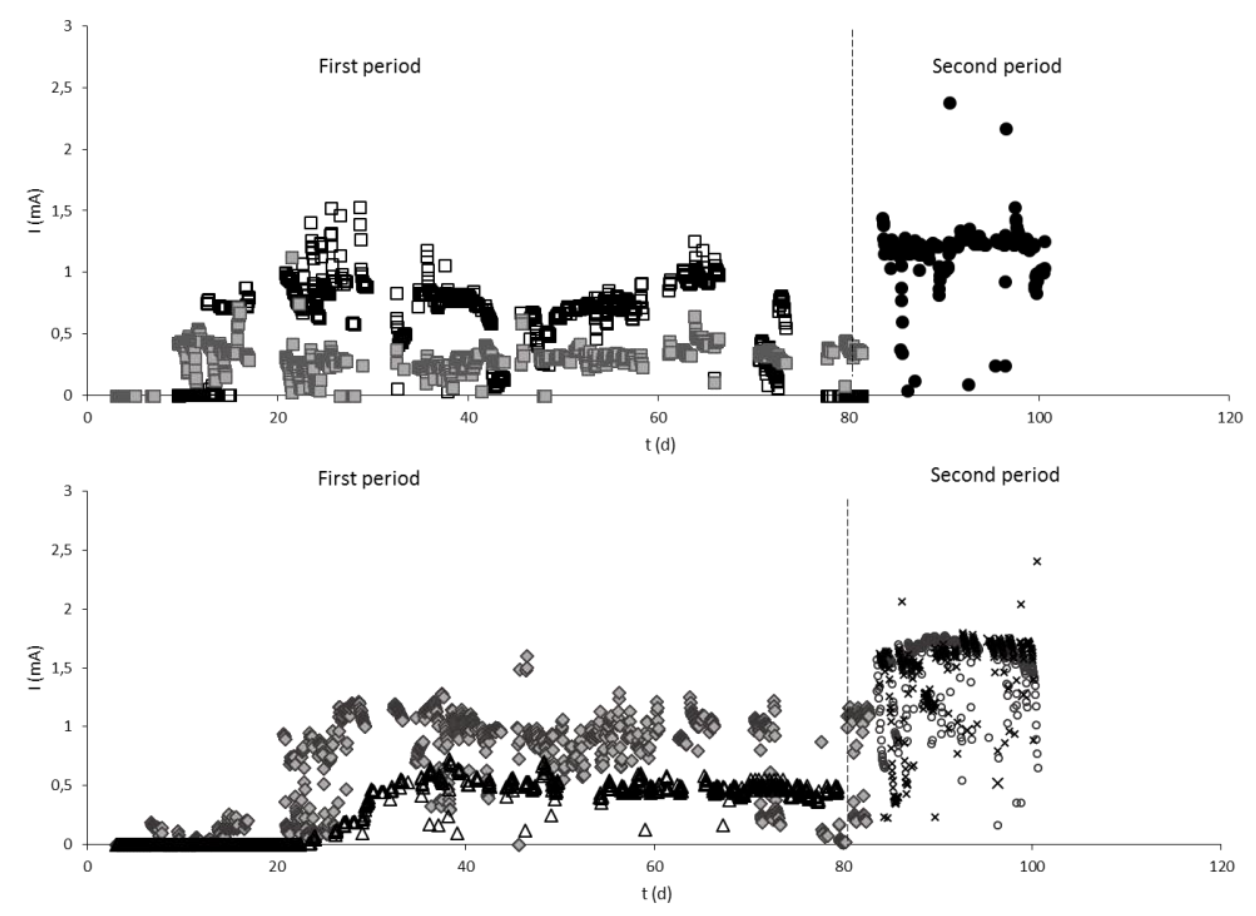

Figure 5. Changes in the current intensity produced during the tests. Separated MFCs of Stack 1 ( $\square$ MFC1 and $\square$ MFC2) prior to their electrical connection; Stack 1 connected in parallel $(\bullet)$; Stack 2 connected in series $(\diamond)$; Stack 2 connected in parallel $(O)$; Stack 3 connected in series $(\triangle)$; Stack 3 connected in parallel $(\mathrm{x})$. 
Regarding Stacks 2 and 3 (Part B of the figure), they were connected in series during the first period (80 days) and then the electric connection was changed to parallel during the last 20 days. The first important point is that series connection is expected to increase the cell voltage and it should not have an effect on the intensity. On the contrary, a parallel connection is expected to increase the current. However, opposite to what was expected, the intensity produced in Stack 3 not is not the same as in Stack 2 but is much lower. This difference and unexpected result can only be explained in terms of an increase in the ohmic resistance of the system associated with its larger size.

On the other hand, in comparing the two operation periods with each of Stacks 2 and 3, it can be seen that the change from series to parallel connection corresponds to an increase in the current intensity, up to a value that is slightly over the maximum intensity obtained for Stack 1. This value is about the same for the two stacks (Stack 2 and Stack 3). In this second case, it has to be taken into account that COD is almost depleted and hence that fuel might be limiting the process. At this point, Figure 6 shows the relationship between the current produced and the COD consumed, which seems to support this explanation.
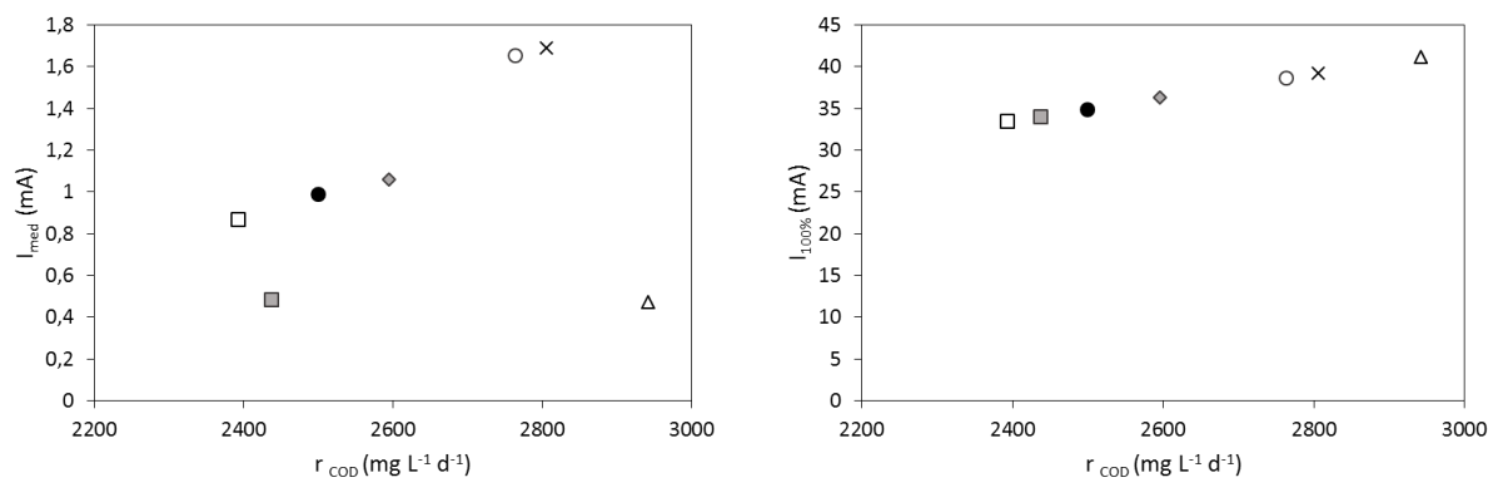

Figure 6. Relationship between COD consumption and current intensity produced and maximum current density achievable for $100 \%$ electric efficiency. Separated MFCs of Stack 
1 ( $\square$ MFC1 and $\square$ MFC2) prior to their electrical connection; Stack 1 connected in parallel $(\bullet)$; Stack 2 connected in series $(\diamond)$; Stack 2 connected in parallel $(O)$; Stack 3 connected in series $(\triangle)$; Stack 3 connected in parallel $(\mathrm{x})$.

Polarization curves were measured at selected days within the operation of the three stacks. One representative polarization curve, obtained at the stationary conditions for each stack, is shown in Figure 7.

As can be observed, the shape of the polarization curves is as expected, with two zones clearly marked: the activation and the ohmic losses. The mass transfer zone is only guessed at in MFC1 when operated in a non-stacked mode. The absence of this zone in all the other polarization curves is typical of the behaviour of MFCs and it can be explained in terms of the very high ohmic losses of these systems, which completely mask this zone.
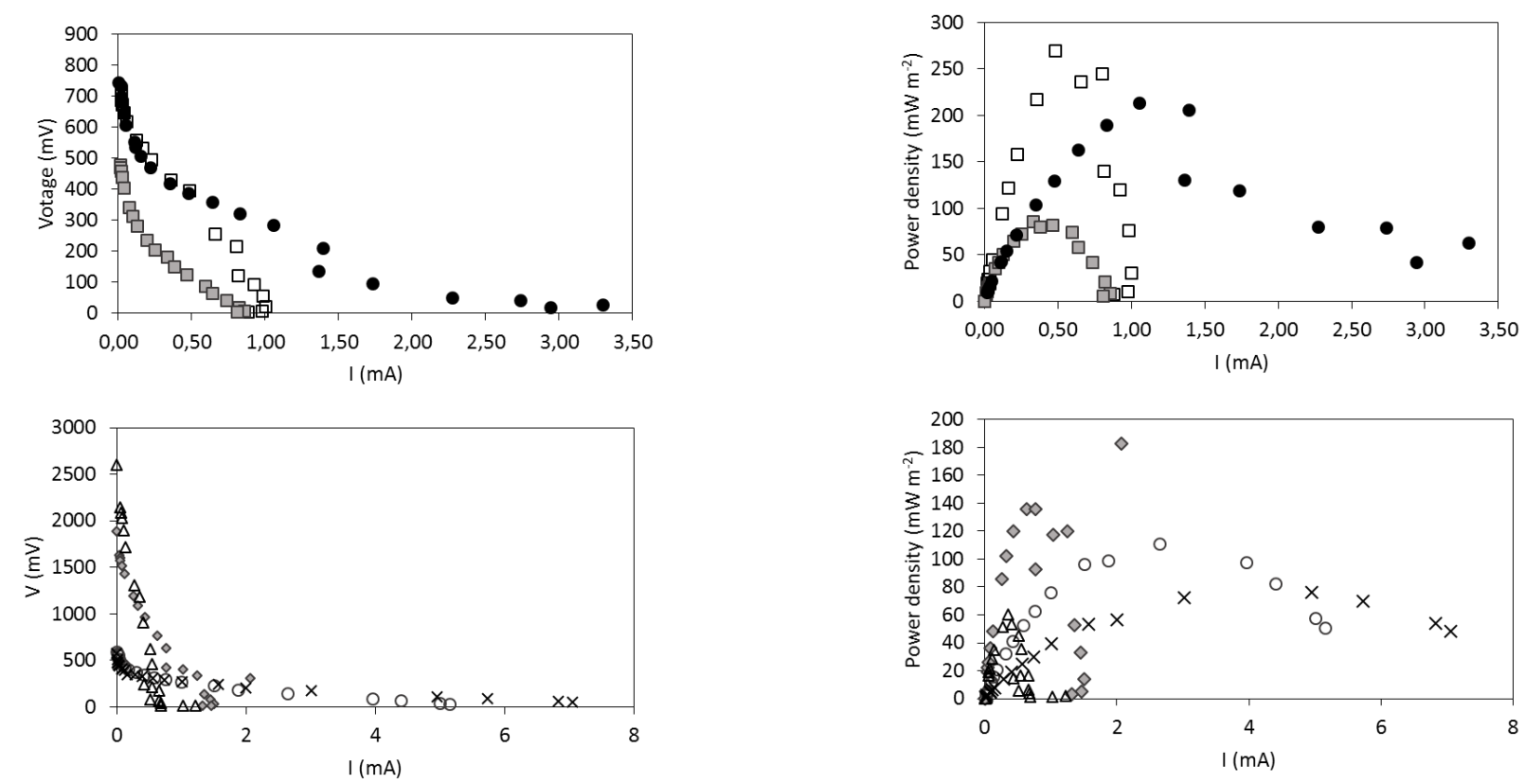

Figure 7. Polarization curves of Stacks 1, 2, and 3. Separated MFCs of Stack 1 ( $\square$ MFC1 and $\square$ MFC2) prior to their electrical connection; Stack 1 connected in parallel $(\bullet)$; Stack 2 
connected in series $(\diamond)$; Stack 2 connected in parallel $(O)$; Stack 3 connected in series $(\triangle)$; Stack 3 connected in parallel (x).

As expected, the connection in series of the MFCs leads to a very important increase in the $\mathrm{OCV}$, while the connection in parallel leads to an increase in the maximum attainable current. Thus, in Stack 1 it can be observed how when the electrodes were connected in parallel the Imax was double than when studying the single-MFCs, due to the sum of the intensities of both single-MFCs, increasing the output energy of the system. The OCV of MFCs connected in series is larger. This is very noticeable in Part B for Stacks 2 and 3 but not in Stack 1.
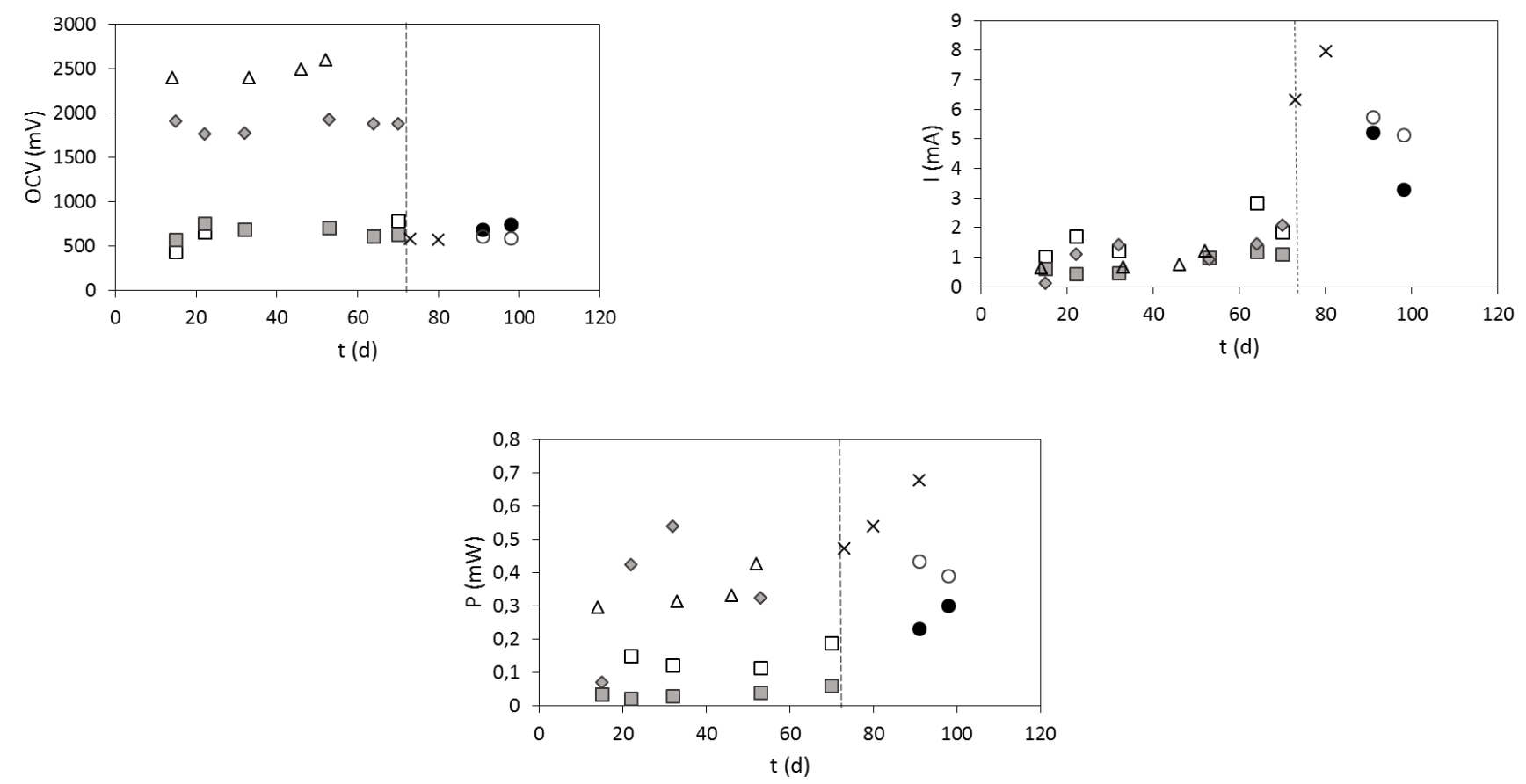

Figure 8. Time course of the parameters that define the polarization curves during the two experimental periods evaluated. Separateds MFC of Stack 1 ( $\square$ MFC1 and $\square$ MFC2) prior to their electrical connection; Stack 1 connected in parallel $(\bullet)$; Stack 2 connected in series $(\diamond)$; Stack 2 connected in parallel $(O)$; Stack 3 connected in series $(\triangle)$; Stack 3 connected in parallel (x). 
On the other hand, as the power density is the product of the voltage and intensity, no great variations in the maximum power densities are found when comparing systems connected in series and parallel, although the shape of the power vs intensity curves is completely different.

The results shown in Figure 7 correspond to one arbitrarily selected operation day. The changes over the operation time in the three most relevant parameters that define the polarization curves (OCV, maximum intensity and maximum power) are shown in Fig 8. This figure confirms the points raised in Figure 7. OCV increases with the number of cells connected in series while maximum intensity with the number of cells is connected in parallel. The maximum intensity in the stack with $10 \mathrm{MFC}$ is $8 \mathrm{~mA}$, which is less than double than the nearly $6 \mathrm{~mA}$ that can be attained with the stack of five cells and slightly over the maximum value obtained by the stack of two cells. It should be taken into account that this non-linear trend can be explained in terms of the consumption of fuel, which seems to be limiting in Stack 2 and especially in Stack 3. Regarding the OCV, the higher it is, the same can be found: in using only one cell, OCV is around $500 \mathrm{mV}$ and this value increases to nearly $1800 \mathrm{mV}$ in the stack of five cells (Stack 2) and to almost $2500 \mathrm{mV}$ in Stack 3 (10 cells).

\section{Conclusions}

From this work, the following conclusions can be drawn:

- Single MFCs can be connected in series or parallel. Connection in series does not show any relevant influence on the performance (except for an increase in the OCV) but connection in parallel allows the bioelectrochemical device to produce higher 
amounts of electricity than the single system, and they also allow the device to get a higher removal of COD.

- Reproducibility of MFC technology is low, and in comparing two single MFC systems that have undergone exactly the same conditions, very important differences are found. Multiparametricity is the cause of this large variation.

- Bulk processes occurring out of the vicinity of electrodes are relevant, but COD consumption and electricity produced depends directly on the total surface area of the device.

- In totally connected systems (from the hydraulic point of view), a higher number of stacked cells is not a guarantee of higher electricity production. Depletion of the fuel and higher resistance can explain this unexpected result.

\section{Acknowledgements}

Financial support from the Spanish Ministry of Economy and Competitiveness (MINECO) through project CTQ2013-49748-EXP (Explora Program) is gratefully acknowledged

\section{References}

1. Lovley DR (2006) Microbial fuel cells: novel microbial physiologies and engineering approaches. Current Opinion in Biotechnology 17:327-332.

2. Rahimnejad M, Ghoreyshi AA, Najafpour GD, Younesi H, Shakeri M (2012) A novel microbial fuel cell stack for continuous production of clean energy. International Journal of Hydrogen Energy 37:5992-6000.

3. Logan BE, Rabaey K (2012) Conversion of Wastes into Bioelectricity and Chemicals by Using Microbial Electrochemical Technologies. Science 337:686-690.

4. Mink JE, Qaisi RM, Logan BE, Hussain MM (2014) Energy harvesting from organic liquids in micro-sized microbial fuel cells. Npg Asia Materials 6.

5. Logan BE(2012) Essential Data and Techniques for Conducting Microbial Fuel Cell and other Types of Bioelectrochemical System Experiments. Chemsuschem 5:988-994. 
6. Logan BE, Hamelers B, Rozendal RA, Schrorder U, Keller J, Freguia S, Aelterman P, Verstraete W, Rabaey K (2006) Microbial fuel cells: Methodology and technology. Environmental Science \& Technology 40:5181-5192.

7. Logan BE (2005) Simultaneous wastewater treatment and biological electricity generation. Water Science and Technology 52:31-37.

8. Bebelis S, Bouzek K, Cornell A, Ferreira MGS, Kelsall GH, Lapicque F, de Leon CP, Rodrigo MA, Walsh FC (2013) Highlights during the development of electrochemical engineering. Chemical Engineering Research \& Design 91:1998-2020.

9. Oh SE, Logan BE (2007) Voltage reversal during microbial fuel cell stack operation. J. Power Sources 167: 11-17.

10. Rodrigo MA, Cañizares P, Lobato J, Paz R, Sáez C, Linares JJ (2007) Production of electricity from the treatment of urban waste water using a microbial fuel cell. J. Power Sources 169:198-204.

11. Zhou M, Chi M, Luo J, He H, Jin T (2011) An overview of electrode materials in microbial fuel cells. J. Power Sources 196:4427-4435.

12. Dumas C, Mollica A, Feron D, Basseguy R, Etcheverry L, Bergel A (2008) Checking graphite and stainless anodes with an experimental model of marine microbial fuel cell. Bioresource Technology 99:8887-8894.

13. Champavert J, Rejeb SB, Innocent C, Pontié M (2015) Microbial fuel cell based on Ni-tetra sulfonated phthalocyanine cathode and graphene modified bioanode. Journal of Electroanalytical Chemistry 757:270-276.

14. Mbokou SF, Tonle IK, Pontié M (2017) Development of a novel hybrid biofuel cell type APAP/O2 based on a fungal bioanode with a Scedosporium dehoogii biofilm. Journal of Electroanalytical Chemistry 47:273-280.

15. Mateo S, Rodrigo M, Fonseca LP, Cañizares P, Fernandez-Morales FJ(2015) Oxygen availability effect on the performance of air-breathing cathode microbial fuel cell. Biotechnology Progress 31:900-907.

16. Cercado-Quezada B, Delia M-L, Bergel A (2011) Electrochemical micro-structuring of graphite felt electrodes for accelerated formation of electroactive biofilms on microbial anodes. Electrochemistry Communications 13:440-443.

17. Aelterman P, Rabaey K, Pham HT, Boon N, Verstraete W (2006) Continuous electricity generation at high voltages and currents using stacked microbial fuel cells. Environmental Science and Technology 40:3388-3394.

18. Sotres A, Díaz-Marcos J, Guivernau M, Illa J, Magrí A, Prenafeta-Boldú FX, Bonmatí A, Viñas $M(2015)$ Microbial community dynamics in two-chambered microbial fuel cells: Effect of different ion exchange membranes. Journal of Chemical Technology and Biotechnology 90: 1497-1506.

19. Dumas C, Basseguy R, Bergel A (2008) Microbial electrocatalysis with Geobacter sulfurreducens biofilm on stainless steel cathodes. Electrochimica Acta 53: 2494-2500.

20. Debuy S, Pecastaings S, Bergel A, Erable B (2015) Oxygen-reducing biocathodes designed with pure cultures of microbial strains isolated from seawater biofilms. International Biodeterioration \& Biodegradation 103:16-22.

21. Bridier A, Desmond-Le Quemener E, Bureau C, Champigneux P, Renvoise L, Audic JM, Blanchet E, Bergel A, Bouchez T (2015) Successive bioanode regenerations to maintain efficient current production from biowaste: Bioelectrochemistry 106:133-140.

22. Huang L, Cheng S, Chen G (2011) Bioelectrochemical systems for efficient recalcitrant wastes treatment. Journal of Chemical Technology and Biotechnology 86:481-491. 
23. Rabaey K, Verstraete W (2005) Microbial fuel cells: novel biotechnology for energy generation. Trends in Biotechnology 23:291-298.

24. Cercado-Quezada B, Delia M-L, Bergel A (2010) Testing various food-industry wastes for electricity production in microbial fuel cell. Bioresource Technology 101:2748-2754.

25. Di Lorenzo M, Thomson AR, Schneider K, Cameron PJ, leropoulos I (2014) A small-scale air-cathode microbial fuel cell for on-line monitoring of water quality. Biosensors \& Bioelectronics 62:182-188.

26. Logan BE (2010) Scaling up microbial fuel cells and other bioelectrochemical systems. Applied Microbiology and Biotechnology 85:1665-1671.

27. Ieropoulos I, Greenman J, Melhuish C (2008) Microbial fuel cells based on carbon veil electrodes: Stack configuration and scalability. International Journal of Energy Research 32:1228-1240.

28. Lacroix R, Da Silva S, Gaig MV, Rousseau R, Delia M-L, Bergel A (2014) Modelling potential/current distribution in microbial electrochemical systems shows how the optimal bioanode architecture depends on electrolyte conductivity. Physical Chemistry Chemical Physics 16:22892-22902.

29. Zhuang L, Yuan Y, Wang Y, Zhou S (2012) Long-term evaluation of a 10-liter serpentinetype microbial fuel cell stack treating brewery wastewater. Bioresource Technology 123:406-412.

30. Ledezma P, Stinchcombe A, Greenman J, leropoulos I (2013) The first self-sustainable microbial fuel cell stack. Physical Chemistry Chemical Physics 15:2278-2281.

31. Boghani HC, Papaharalabos G, Michie I, Fradler KR, Dinsdale RM, Guwy AJ, leropoulos I, Greenman J, Premier GC (2014) Controlling for peak power extraction from microbial fuel cells can increase stack voltage and avoid cell reversal. J. Power Sources 269: 363-369.

32. An J, Sim J, Lee H-S (2015) Control of voltage reversal in serially stacked microbial fuel cells through manipulating current: Significance of critical current density. J. Power Sources 283 19-23.

33. Khaled F, Ondel O, Allard B (2015) Optimal Energy Harvesting From Serially Connected Microbial Fuel Cells. leee Transactions on Industrial Electronics 62: 3508-3515.

34. Ledezma P, Greenman J, leropoulos I (2013) MFC-cascade stacks maximise COD reduction and avoid voltage reversal under adverse conditions. Bioresource Technology 134: 158165.

35. Winfield J, leropoulos I, Greenman J, Dennis J (2011) Investigating the effects of fluidic connection between microbial fuel cells. Bioprocess and Biosystems Engineering 34: 477484.

36. Hsu L, Chadwick B, Kagan J, Thacher R, Wotawa-Bergen A, Richter K (2013) Scale up considerations for sediment microbial fuel cells. Rsc Advances 3:15947-15954.

37. Hiegemann H, Herzer D, Nettmann E, Lubken M, Schulte P, Schmelz K-G, GredigkHoffmann S, Wichern M (2016) An integrated 45L pilot microbial fuel cell system at a fullscale wastewater treatment plant. Bioresource technology 218:115-22.

38. Wu S, Li H, Zhou X, Liang P, Zhang X, Jiang Y, Huang X (2016) A novel pilot-scale stacked microbial fuel cell for efficient electricity generation and wastewater treatment. Water Research 98:396-403.

39. An B-M, Heo Y, Maitlo H-A, Park J-Y (2016) Scaled-up dual anode/cathode microbial fuel cell stack for actual ethanolamine wastewater treatment. Bioresource Technology 210:6873. 
40. Liu B, Williams I, Li Y, Wang L, Bagtzoglou A, McCutcheon J, Li B (2016) Towards high power output of scaled-up benthic microbial fuel cells (BMFCs) using multiple electron collectors. Biosensors \& Bioelectronics 79:435-441.

41. Walter XA, Gajda I, Forbes S, Winfield J, Greenman J, leropoulos I (2016) Scaling-up of a novel, simplified MFC stack based on a self-stratifying urine column. Biotechnology for Biofuels 9.

42. Salar-García MJ, Ortiz-Martínez VM, Baicha Z, de los Ríos AP, Hernández-Fernández FJ (2016) Scaled-up continuous up-flow microbial fuel cell based on novel embedded ionic liquid-type membrane-cathode assembly. Energy 101:113-120.

43. Watanabe K (2008) Recent Developments in Microbial Fuel Cell Technologies for Sustainable Bioenergy. Journal of Bioscience and Bioengineering 106:528-536.

44. Pant D, Van Bogaert G, Diels L, Vanbroekhoven K (2010) A review of the substrates used in microbial fuel cells (MFCs) for sustainable energy production. Bioresource Technology 101: 1533-1543.

45. Dekker A, Ter Heijne A, Saakes M, Hamelers HVM, Buisman CJN (2009) Analysis and Improvement of a Scaled-Up and Stacked Microbial Fuel Cell. Environmental Science \& Technology 43:9038-9042.

46. Penteado ED, Fernandez-Marchante CM, Zaiat M, Cañizares P, Gonzalez ER, Rodrigo MA (2016) Influence of sludge age on the performance of MFC treating winery wastewater. Chemospher 151: 163-170.

47. Asensio Y, Montes IB, Fernandez-Marchante CM, Lobato J, Cañizares P (2017) Selection of cheap electrodes for two-compartment microbial fuel cells. Journal of Electroanalytical Chemistry 785: 235-240. 
